\title{
Impact of tillage practices on water use and energy efficiency in cotton under rainfed condition
}

Chitte Karishma and S.M.Taley

Received : 25.09.2019; Revised : 04.05.2020; Accepted : 21.05.2020

MEMBERS OF RESEARCH FORUM:

Corresponding author :

Chitte Karishma, Dr. Panjabrao Deshmukh Krishi Vidyapeeth, Akola (M.S.) India

Email: karichitte030@gmail.com

Co-authors :

S.M.Taley, Department of Soil and

Water Conservation Engineering, Dr.

Panjabrao Deshmukh Krishi

Vidyapeeth, Akola (M.S.) India

\section{Summary}

The field experiment was conducted at Central Research Station (CRS) of Dr. Panjabrao Deshmukh Krishi Vidyapeeth, Akola. The experiment field consist of 6 different treatments and 4 replications viz., conservation tillage (1 blade harrow before sowing) $\left(\mathrm{T}_{1}\right)$, conservation tillage (1 Tyne+1 blade harrow) $\left(\mathrm{T}_{2}\right)$, sub- surface tillage ( $90 \mathrm{~cm} \mathrm{H.I+2} \mathrm{Tyne+} \mathrm{blade} \mathrm{harrow)}$ $\left(\mathrm{T}_{3}\right)$. Economical sub-surface tillage ( 1 sub surface +1 tyne +1 blade harrow) $\left(\mathrm{T}_{4}\right), 1$ Ploughing + 2 Tyne +1 blade harrow $\left(\mathrm{T}_{5}\right)$, Across the slope cultivation with opening of BBF after two row +2 tyne +1 blade harrow $\left(\mathrm{T}_{6}\right)$. Water use efficiency was more dominant in treatment $\mathrm{T}_{3}$ $\left(2.92 \mathrm{~kg} \mathrm{ha}^{-1} \mathrm{~mm}^{-1}\right)$, the energy efficiency is maximum for treatment $\mathrm{T}_{3}(3.7)$ followed by treatments, $\mathrm{T}_{4}, \mathrm{~T}_{5}, \mathrm{~T}_{6}, \mathrm{~T}_{2}$ and $\mathrm{T}_{1}$.

Key words : Harrow, Efficiency, Tillage, Conservation, Energy

How to cite this article : Karishma, Chitte and Taley, S.M. (2020). Impact of tillage practices on water use and energy efficiency in cotton under rainfed condition. Asian J. Soil Sci., 15 (1) : 22-26 : DOI : 10.15740/HAS/AJSS/15.1/22-26. Copyright@ 2020: Hind Agri-Horticultural Society. 